\title{
The effect of sugars in relation to methyl jasmonate on anthocyanin formation in the roots of Kalanchoe blossfeldiana (Poelln.)
}

\author{
Justyna Góraj-Koniarska*, Marian Saniewski \\ Research Institute of Horticulture, Konstytucji 3 Maja 1/3, 96-100 Skierniewice, Poland
}

\begin{abstract}
This study investigated the effects of different sugars (sucrose, fructose, glucose) and sugar alcohols (mannitol, sorbitol) applied alone and in solution with methyl jasmonate (JA-Me) on the anthocyanin content in the roots of Kalanchoe blossfeldiana. None of the sugars used individually in the experiment affected anthocyanin accumulation in the roots of intact plants. The anthocyanin level was similar to that in the control. Sucrose at concentrations of $0.5 \%$ and $3.0 \%$, and glucose at a concentration of $3.0 \%$ inhibited anthocyanin accumulation induced by JA-Me. Only fructose at a concentration of $3.0 \%$ stimulated anthocyanin accumulation induced by JA-Me. The sugar alcohols, mannitol at a concentration of $3.0 \%$ and sorbitol at $0.5 \%$ and $3.0 \%$, inhibited anthocyanin accumulation in the roots of intact K. blossfeldiana plants induced by JA-Me. In excised roots, both sugars and JA-Me used individually did not affect the formation of anthocyanins. Also, the sugar alcohols (mannitol and sorbitol) applied simultaneously with JA-Me had no effect on the accumulation of anthocyanins. However, roots treated with sugars (sucrose, fructose, glucose) in solution with JA-Me promoted the induction of anthocyanins in the apical parts of the roots.

The results suggest that anthocyanin elicitation in the roots of $K$. blossfeldiana by methyl jasmonate may be dependent on the interaction of JA-Me with sugars transported from the stems (leaves) to the roots.
\end{abstract}

Keywords: sugars; sugar alcohols; anthocyanins; roots; Kalanchoe blossfeldiana

\section{Introduction}

The accumulation of anthocyanins in the leaves, stem and roots is often a response of the plant to environmental stresses. Anthocyanin synthesis can be modulated by various factors such as light, plant growth regulators, sugars, and cold stress. Also, the ability to induce anthocyanins is sometimes limited by a specific phase of plant development [1].

Sugars in plants are not only a source of energy released in the process of respiration and structural compounds but they also act as a physiological signal. Various sugars, like sucrose and maltose, can activate sugar specific signaling pathways [2]. The physiological functions of sugars are very diverse. A local increase in the concentration of sugars in different organs or individual cells contributes to the induction of plant flowering, an increase in the number of tubers in potato, and inhibition of seed germination. Sugars also fulfill an osmoregulatory function in disturbances caused by various stresses and protect cellular structures in conditions of low temperature or salinity [3].

\footnotetext{
* Corresponding author. Email: justyna.goraj@inhort.pl
}

Handling Editor: Elżbieta Weryszko-Chmielewska
Sugars are important factors in the accumulation of anthocyanins, especially in plants cultured in vitro and in germinating plants $[4,5]$. Different sugars have been found to enhance anthocyanin accumulation in carrot [6], udo [7], and strawberry [8] grown in nutrient media. Ram et al. [9] investigated the promotion of anthocyanins in leaf calluses in Rosa hybrida 'Pusa Ajay' by different sucrose concentrations. High levels of anthocyanins were obtained in Rosa cultures on Euphorbia millii medium containing $6.0 \%$ or $7.0 \%$ sucrose. However, sucrose at a concentration of $7.0 \%$ was the most effective [9].

Sugar is an integral factor in the development of flower and petal pigmentation. Increased sugar levels intensify the color of flower petals in Liatris spicata [10], Eustoma grandiflorum [11], and Hyacinthus orientalis [12].

It has been found that sugars stimulate anthocyanin biosynthesis and accumulation in the cells of Vitis vinifera [13] and Raphanus sativus [14].

Signal transductions induced by sugars interact with hormonal pathways, which forms a complex and extensive signaling network. Many relationships between sugars and plant hormones have been demonstrated, their effect and that of other factors on embryogenesis, germination of seeds, and the early stages of plant development $[15,16]$. 
We previously reported that methyl jasmonate affected the induction of anthocyanins in the roots of intact Kalanchoe blossfeldiana plants under natural light conditions in a greenhouse [17,18] (Fig. 1). In isolated roots of K. blossfeldiana, however, JA-Me had no effect on anthocyanin synthesis. The roots were creamy, as in the control.

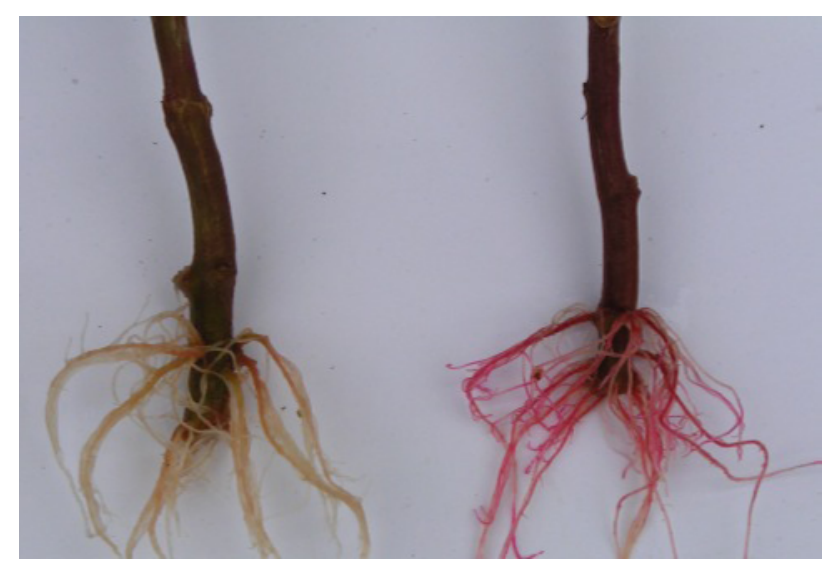

\section{Control JA-Me $20 \mathrm{mg}^{-1}$}

Fig. 1 Roots of intact plants of Kalanchoe blossfeldiana immersed in distilled water (control) and treated with methyl jasmonate (JA$\mathrm{Me}$ ) at $20 \mathrm{mg} \mathrm{l}^{-1}$, photographed 14 days after treatment.

The accumulation of anthocyanins by sugars has been observed and well characterized in flowers and fruits, but not in the roots. Hara et al. [14] investigated the effect of sugars on anthocyanin content in Raphanus sativus hypocotyls. However, there has been little research on the interaction between sugars and JA-Me in anthocyanin synthesis in vegetative tissues.

In this paper, we report how sugars and sugar alcohols applied alone and simultaneously with JA-Me influence the accumulation of anthocyanins in the roots of intact Kalanchoe blossfeldiana plants and in excised roots of these plants.

\section{Material and methods}

\section{Plant material and treatments}

Kalanchoe blossfeldiana (Poelln.) is a popular house plant that comes from Madagascar. Cuttings for the experiment were obtained from mature plants cultivated in a greenhouse of the Research Institute of Horticulture. Seedlings were rooted in distilled water. Roots of intact plants or excised roots were kept in solutions of sugars (sucrose, glucose, fructose) or sugar alcohols (sorbitol, mannitol) used individually and combined with JA-Me. Based on the literature data, we tested various concentrations of sugars and JA-Me. In the experiment, we used two intermediate concentrations of sugars: $0.5 \%$ and $3.0 \%$, and JA-Me at $20 \mathrm{mg} \mathrm{l}^{-1}(89.2 \mu \mathrm{M})$. Sugar concentrations higher than $3 \%$ had a toxic effect on the roots of intact $K$. blossfeldiana plants. It was observed that seedlings treated with JA-Me above $40 \mathrm{mg} \mathrm{l}^{-1}$ were losing leaves.
The roots of intact plants and excised roots were soaked in solutions of the test compounds and maintained for two weeks under natural light conditions in a greenhouse. The control plants were Kalanchoe blossfeldiana seedlings immersed in distilled water. Separate experiments for each sugar for intact plants and excised roots were carried out from January to June. The temperature in the greenhouse was $22 \pm 3^{\circ} \mathrm{C} / 18 \pm 3^{\circ} \mathrm{C}$ (day/night).

\section{Anthocyanin measurements}

Roots of intact plants of Kalanchoe blossfeldiana were collected after 14 days from the start of the experiment. Anthocyanin content in the roots was analyzed according to the method described by Mancinelli et al. [19] with small modifications. In the isolated (excised) roots the level of anthocyanins was not measured and only morphological observations were made.

The pigment was extracted for $24 \mathrm{~h}$ at $4^{\circ} \mathrm{C}$ in $5 \mathrm{ml}$ methanol containing $1 \% \mathrm{HCl}$. Then, the extract was centrifuged at $6000 \times g$ for $10 \mathrm{~min}$. After centrifugation, the anthocyanin content in the supernatant was estimated by measuring absorbance at $530 \mathrm{~nm}$ using a spectrophotometer. The total anthocyanin content was calculated using the extinction coefficient value 29600 of cyanidin-3-glucoside and expressed in $\mu \mathrm{g} \mathrm{g}^{-1}$ fresh weight (FW).

Five to seven plants were used for each treatment. The results are the mean of five independent replicates. The results were statistically processed using variance analysis. To evaluate the differences between means, Duncan's multiple range test was used, assuming the level of significance at $P=0.05$.

\section{Results}

\section{Intact plants}

The levels of anthocyanins in K. blossfeldiana (Poelln.) roots after separate treatments with sugars and in combination with JA-Me at $20 \mathrm{mg} \mathrm{l}^{-1}(89.2 \mu \mathrm{M})$ were analyzed. The results showed that the applications of sucrose, fructose, and glucose individually in the solution did not affect the accumulation of anthocyanins in the roots of intact Kalanchoe blossfeldiana plants (Fig. 2-Fig. 4). The anthocyanin content in the control plants (distilled water) was $82.5 \mu \mathrm{g} \mathrm{g}^{-1} \mathrm{FW}$, while after treatment with sucrose it was $70.30 \mu \mathrm{g} \mathrm{g}^{-1} \mathrm{FW}$ (Fig. 2).

When sucrose $(0.5 \%, 3.0 \%)$ and glucose $(3.0 \%)$ were applied to the roots together with JA-Me, inhibition of anthocyanin accumulation induced by JA-Me was found (Fig. 2, Fig. 4). Only fructose at a concentration of 3.0\% stimulated anthocyanin accumulation induced by JA-Me. After the combined treatment with fructose and JA-Me, the anthocyanin content in the roots increased by approx. 45\% (Fig. 3).

Fig. 5 and Fig. 6 summarize the results of the experiment with the sugar alcohols, mannitol and sorbitol, applied individually and in solution with JA-Me in the promotion of anthocyanins in the roots of intact $K$. blossfeldiana plants.

The experiment demonstrated that the sugar alcohols, mannitol and sorbitol ( $0.5 \%$ and $3.0 \%)$, applied individually had no effect on anthocyanin accumulation in K. blossfeldiana roots. The level of anthocyanins after treatment with sugar 


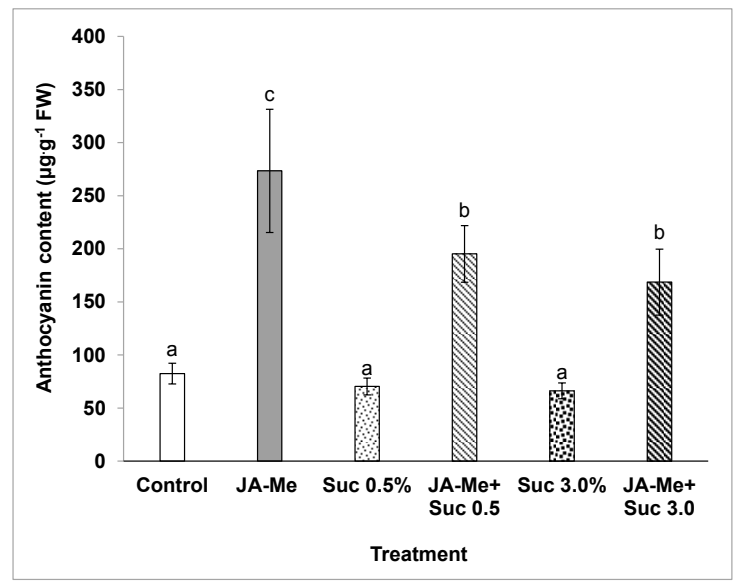

Fig. 2 Effect of sucrose (Suc 0.5 and 3.0\%) used alone and combined with methyl jasmonate $\left(20 \mathrm{mg} \mathrm{l}^{-1}\right)$ on anthocyanin accumulation in the roots of $K$. blossfeldiana. Means followed by the same letter are not significantly different at $P=0.05$ according to Duncan's test. Error bars indicate $\pm S D(n=10)$.

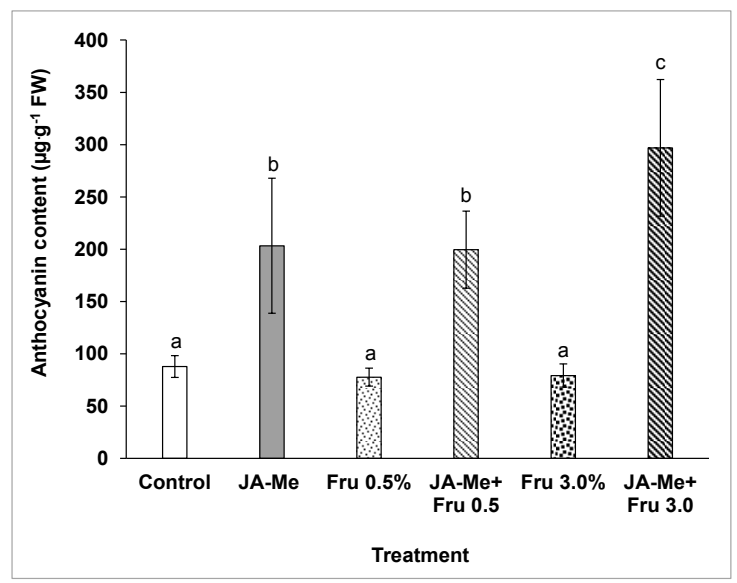

Fig. 3 Effect of fructose (Fru 0.5 and 3.0\%) used alone and combined with methyl jasmonate $\left(20 \mathrm{mg} \mathrm{l}^{-1}\right)$ on anthocyanin accumulation in the roots of $K$. blossfeldiana. Means followed by the same letter are not significantly different at $P=0.05$ according to Duncan's test. Error bars indicate $\pm S D(n=10)$.

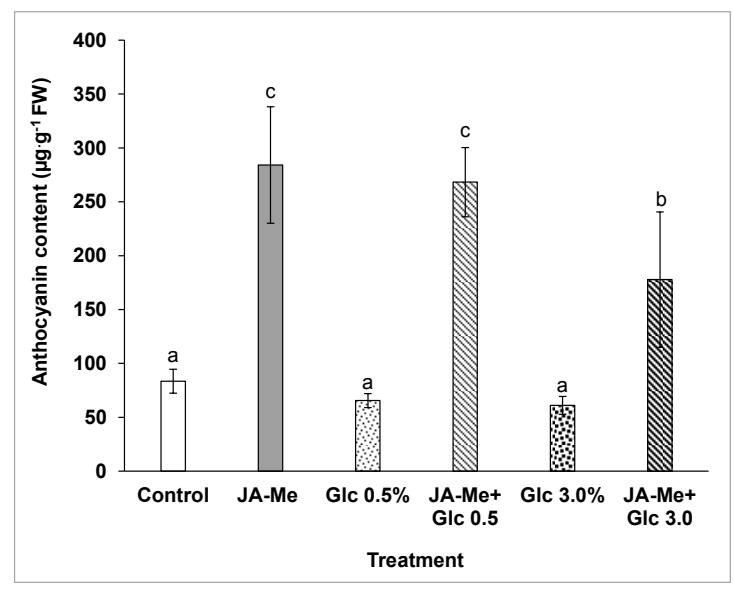

Fig. 4 Effect of glucose (Glc 0.5 and 3.0\%) used alone and combined with methyl jasmonate $\left(20 \mathrm{mg} \mathrm{l}^{-1}\right)$ on anthocyanin accumulation in the roots of $K$. blossfeldiana. Means followed by the same letter are not significantly different at $P=0.05$ according to Duncan's test. Error bars indicate $\pm S D(n=10)$.

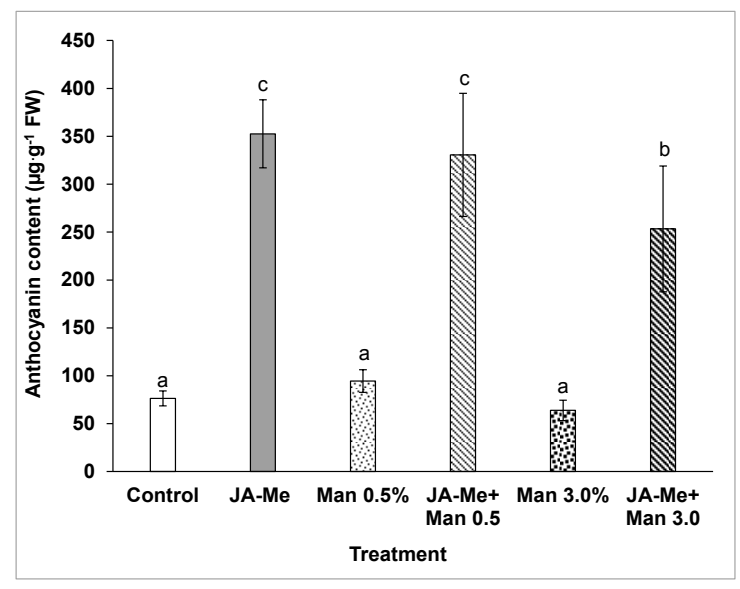

Fig. 5 Effect of mannitol (Man 0.5 and 3.0\%) used alone and combined with methyl jasmonate $\left(20 \mathrm{mg} \mathrm{l}^{-1}\right)$ on anthocyanin accumulation in the roots of $K$. blossfeldiana. Means followed by the same letter are not significantly different at $P=0.05$ according to Duncan's test. Error bars indicate $\pm S D(n=10)$.

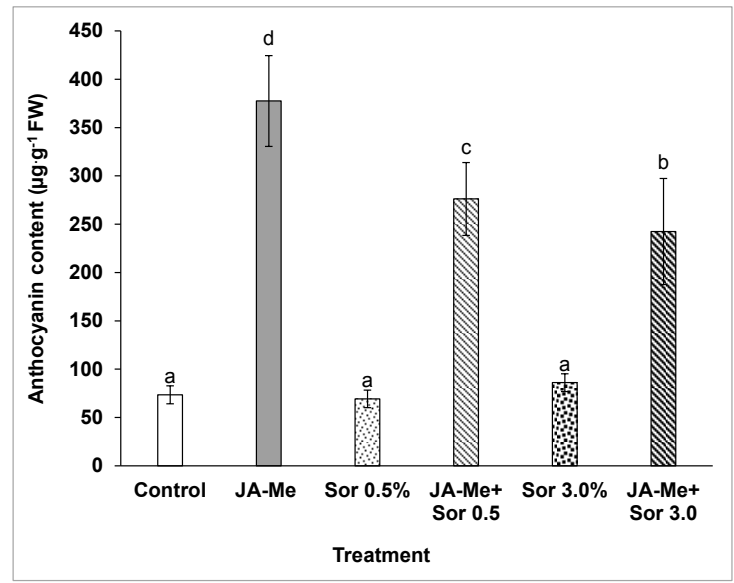

Fig. 6 Effect of sorbitol (Sor 0.5 and 3.0\%) used alone and combined with methyl jasmonate $\left(20 \mathrm{mg} \mathrm{l}^{-1}\right)$ on anthocyanin accumulation in the roots of $K$. blossfeldiana. Means followed by the same letter are not significantly different at $P=0.05$ according to Duncan's test. Error bars indicate $\pm S D(n=10)$.

alcohols was similar to that of the control. The combinations of mannitol (3.0\%) and sorbitol (0.5\% and 3.0\%) with JA-Me reduced the anthocyanin content compared with JA-Me treatment alone (Fig. 5, Fig. 6).

\section{Excised roots}

We found that the sugars (sucrose, glucose, fructose) and JA-Me at $20 \mathrm{mg}^{-1}(89.2 \mu \mathrm{M})$ used individually did not affect the accumulation of anthocyanins in the excised roots of $K$. blossfeldiana under natural light conditions in a greenhouse, as presented in Fig. 7. The sugar alcohols, mannitol and sorbitol (0.5\% and 3.0\%), used alone and in solution with JA-Me did not affect anthocyanin accumulation. The roots remained creamy like those of the control (morphological observations only). It is interesting to note that sucrose, glucose and fructose applied together with JA-Me induced the accumulation of anthocyanins, but only in the apical parts of the roots (Fig. 7). 

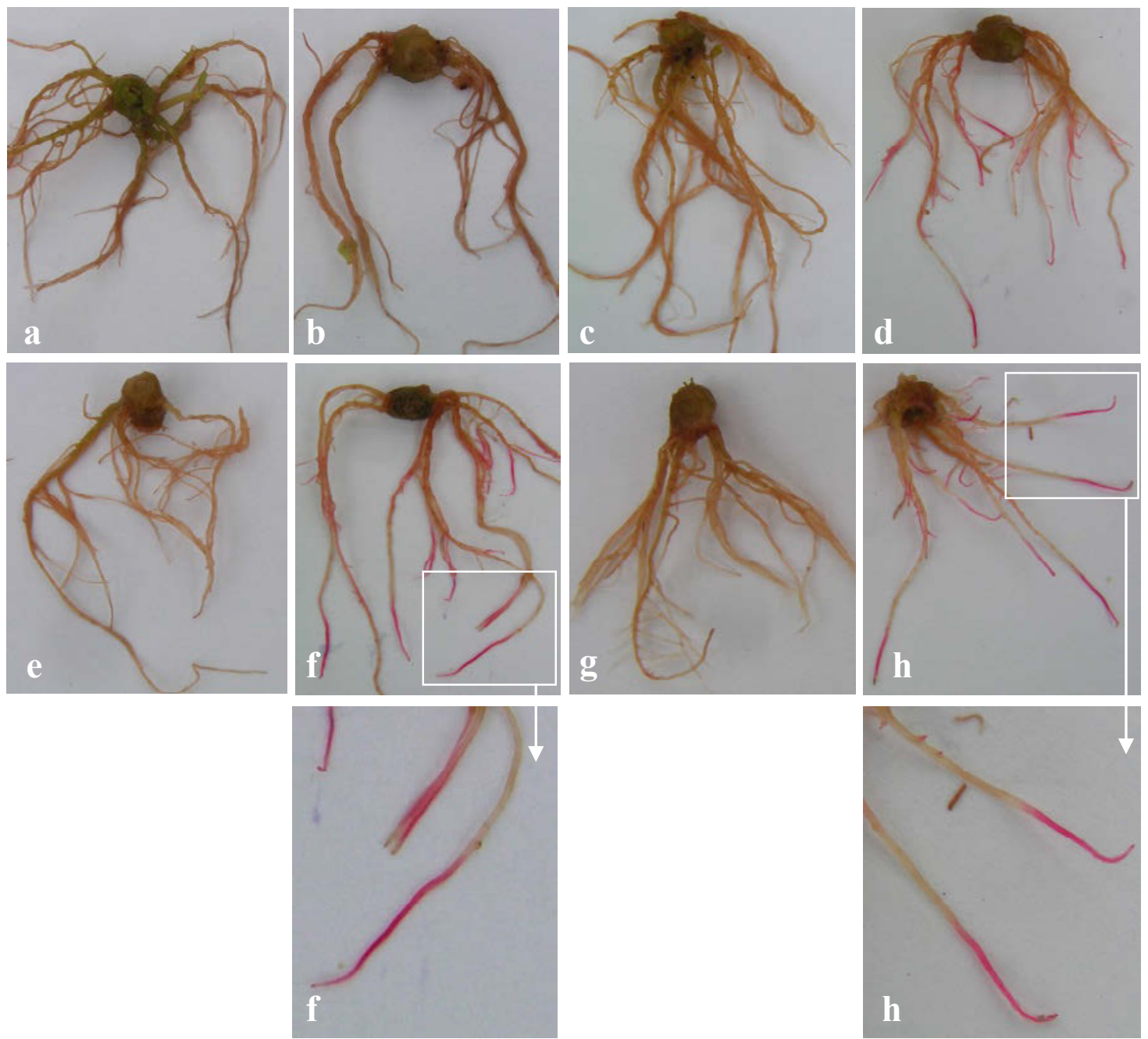

Fig. 7 Effect of sugars (sucrose, glucose, fructose, at 3.0\% each) and their interaction with methyl jasmonate (20 $\left.\mathrm{mg} \mathrm{l}^{-1}\right)$ on anthocyanin accumulation in excised roots of $K$. blossfeldiana, photographed 14 days after treatment. a Control. b JA-Me $20 \mathrm{mg} \mathrm{l}^{-1}$; c Sucrose 3.0\%; d JA-Me + sucrose 3.0\%; e Glucose 3.0\%; f JA-Me + glucose 3.0\%; g Fructose 3.0\%; h JA-Me + fructose $3.0 \%$.

\section{Discussion}

Our research has shown that sugars applied alone to a vegetative organ, the roots of intact $K$. blossfeldiana plants, had no effect on anthocyanin accumulation. In contrast, several studies have indicated positive effects of sugars on anthocyanin biosynthesis. For example, sugars have been found to induce the biosynthesis and accumulation of anthocyanins in the petals of Petunia hybrida [20] and in the fruits of Vitis vinifera [21]. In the skin of grapes, the expression of anthocyanin biosynthesis genes was stimulated after delivery of sugars [21]. According to Vitrac et al. [22], several components of general signal transduction pathways, such as $\mathrm{Ca}^{2+}$, calmodulin, and protein kinases/phosphatases, were involved in the induction of anthocyanin biosynthesis in V. vinifera by sugar. Also, in transgenic Arabidopsis leaves, treatment with sugars induced the expression of the chalcone synthase gene [23]. Plants of Raphanus sativus treated with sucrose at a concentration of $175 \mathrm{mM}$ gave the best results in the induction of anthocyanins in the hypocotyl system, which proves that sugars transported from the leaves to the hypocotyl can stimulate the biosynthesis of anthocyanins by inducing gene expression in radish. Chalcone synthase (CHS) and anthocyanidin synthase (ANS) were particularly active after treatment with sucrose. Interestingly, the addition of sucrose stimulated lateral root formation [14].

We found that the kind of sugars used individually had no effect on the anthocyanin content in the roots of $K$. blossfeldiana. On the other hand, it has been proven that sucrose and glucose are the most effective in the production of anthocyanins in plant cells. However, as osmotic stress signals, sorbitol and mannitol may also induce the biosynthesis of anthocyanins [9,24]. In non-chlorophyllous corn, sugars like fructose, glucose, and sucrose significantly stimulate anthocyanin induction and are also probably important in the regulation of the anthocyanin biosynthesis gene [25].

In a culture of grape berries, glucose, fructose and sucrose enhanced the synthesis of anthocyanins. Dai et al. [26] indicated that increased levels of anthocyanins in grape berries were not caused by an increase in the level of their precursor. The amount of phenylalanine decreased by high sugar treatment. 
Teng et al. [27] investigated the effect of mono- and disaccharides added at a concentration of $100 \mathrm{mM}$ to MS medium on anthocyanin accumulation in Arabidopsis seedlings. Sucrose and maltose greatly stimulated anthocyanin production in the treated plants, but sorbitol did not induce anthocyanin accumulation.

Fructose, glucose, rhamnose, and sucrose were tested for anthocyanin accumulation in cultures of Vitis labruscana 'Olympia'. Almost no effect was observed after adding 2.5\% and $10.0 \%$ glucose, or $2.5 \%$ sucrose to the culture solution, but slight promotion was found following the addition of $2.5 \%$ and $10.0 \%$ fructose and $2.5 \%$ rhamnose, whereas $10.0 \%$ sucrose suppressed anthocyanin accumulation [28].

Sugars and hormones create signaling networks and coordinate many processes involved in plant growth and development [29]. Jasmonates and sugars, especially sucrose, induced the accumulation of anthocyanins and gene expression in, for example, Vitis vinifera [30], or did not support the production of anthocyanins, as in Melostoma malabathricum [31]. In the literature, there is little information on the interaction of jasmonates and sugars in the biosynthesis of anthocyanins in the roots. There is only a report by Shimizu et al. [32] who found that Gynura bicolor plants cultured in a medium containing $1.5-8.0 \%$ sucrose

\section{Acknowledgments}

The research was supported by the Polish Ministry of Science and Higher Education as part of the statutory activities (7.2.1) of the Department of General Biology, Research Institute of Horticulture in Skierniewice.

\section{Authors' contributions}

The following declarations about authors' contributions to the research have been made: design of the experiments: JGK; carried out the experiments: JGK; writing of the manuscript: JGK; MS.

\section{Competing interests}

No competing interests have been declared.

\section{References}

1. Chalker-Scott L. Environmental significance of anthocyanin in plant stress responses. Photochem Photobiol. 1999;70:1-9. http://dx.doi. org/10.1111/j.1751-1097.1999.tb01944.x

2. Das PK, Geul B, Coi SB, Too SD. Park YII. Photosynthesis-dependent anthocyanin pigmentation in Arabidopsis. Plant Signal Behav. 2011;6:23-25. http://dx.doi.org/10.4161/psb.6.1.14082

3. Starck Z. Różnorodne funkcje węgla i azotu w roślinach. Kosmos. 2006;55:243-257.

4. Mita S, Hirano H, Nakamura K. Negative regulation in the expression of a sugar-inducible gene in Arabidopsis thaliana. Plant Physiol. 1997;114:575-582. http://dx.doi.org/10.1104/pp.114.2.575

5. Baier M, Hemmann G, Holman R, Corke F, Card R, Smith C, et al. Characterization of mutants in Arabidopsis showing increased sugarspecific gene expression, growth, and developmental responses. Plant Physiol. 2004;134:81-91. http://dx.doi.org/10.1104/pp.103.031674

6. Rajendran L, Ravishanker GA, Venkataraman LV, Prathiba KR. Anthocyanin production in callus cultures of Daucus carota is influenced by nutrient stress and osmoticum. Biotechnol Lett. 1992;14:707-712. http://dx.doi.org/10.1007/BF01021647

7. Sakamoto K, Iida K, Sawamura K, Hajiro K, Asada Y, Yoshikawa $\mathrm{T}$, et al. Anthocyanin production in cultured cells of Aralia cordata Thunb. Plant Cell Tissue Organ Cult. 1994;36:21-26. http://dx.doi. org/10.1007/BF00048311 together with JA-Me $(25 \mu \mathrm{M})$ accumulated anthocyanins in the roots. The anthocyanin content in Gynura roots cultured in 3\% and 6\% sucrose combined with JA-Me was the highest.

The mechanisms underlying the regulation of anthocyanin synthesis by sugars and JA-Me remain unknown.

In our work, the concentrations of sugars (sucrose, glucose) and sugar alcohols (mannitol, sorbitol) were probably too high for the plants and consequently inhibited the accumulation of anthocyanins induced by JA-Me in the roots of intact $K$. blossfeldiana plants. This is supported by the fact that sucrose and JA-Me applied individually to the excised roots had no effect, but when supplied together, they stimulated anthocyanin accumulation in the apical parts of those roots. Similar results were obtained with the other sugars, glucose and fructose, used in combination with JA-Me.

\section{Conclusion}

It can be concluded that the increase in the level of anthocyanins in the roots of $K$. blossfeldiana induced by JA-Me may be dependent on the interaction of JA-Me with sugars transported from the stems and leaves to the roots.

8. Mori T, Sakurai M. Production of anthocyanin from strawberry cell suspension cultures; effects of sugar and nitrogen. J Food Sci. 1994;59:588-593. http://dx.doi.org/10.1111/j.1365-2621.1994. tb05569.x

9. Ram M, Prasad KV, Kaur Ch, Singh SK, Arora A, Kumar S. Induction of anthocyanin pigments in callus cultures of Rosa hybrida L. in response to sucrose and ammoniacal nitrogen levels. Plant Cell Tissue Organ Cult. 2011;104:171-179. http://dx.doi.org/10.1007/ s11240-010-9814-5

10. Han SS. Role of sucrose in bud development and vase life of cut Liatris spicata (L.). Willd. HortScience. 1992;27:1198-1200.

11. Kawabata S, Ohta SM, Kusuhara Y, Sakiyama R. Influences of low light intensities on the pigmentation of Eustoma grandiflorum flowers. Acta Hortic. 1995;405:173-178.

12. Hosokawa K, Fukunaga Y, Fukushi E, Kawabata J. Production of acylated anthocyanins by blue flowers of Hyacinthus orientalis regenerated in vitro. Phytochemistry. 1996;41:1531-1533. http:// dx.doi.org/10.1016/0031-9422(95)00803-9

13. Larronde F, Krisa S, Decendit A, Cheze C, Merillon JM. Regulation of polyphenol production in Vitis vinifera cell suspension cultures by sugars. Plant Cell Rep. 1998;17:946-950. http://dx.doi.org/10.1007/ s002990050515

14. Hara M, Oki K, Hoshino K, Kuboi T. Enhancement of anthocyanin biosynthesis by sugar in radish (Raphanus sativus) hypocotyl. Plant Sci. 2003;164:259-265. http://dx.doi.org/10.1016/S0168-9452(02)00408-9

15. Gibson SI. Plant sugar-response pathways. Part of a complex regulatory web. Plant Physiol. 2000;124:1532-1539. http://dx.doi.org/10.1104/ pp.124.4.1532

16. Gibson SI. Sugar and phytohormone response pathways: navigating a signaling network. J Exp Bot. 2004;55:253-264. http://dx.doi. org/10.1093/jxb/erh048

17. Góraj J, Saniewski M. Methyl jasmonate induces anthocyanins accumulation in roots of Kalanchoe blossfeldiana. Book of abstracts: 8th international conference "Eco-physiological aspects of plant responses to stress factors", September 16-20, 2009, Cracow, Poland; 2009. p. 101.

18. Góraj J, Stochmal A, Oleszek W, Mołdoch J, Saniewski M. Elicitation of anthocyanins production in the roots of Kalanchoe blossfeldiana by methyl jasmonate. Book of abstracts: "II conference of bioactive 
plant compounds structural and applicative aspects", September 12-14, 2011, Puławy, Poland; 2011. p. 46.

19. Mancinelli AL, Hoff AM, Cottrell M. Anthocyanin production in Chl-rich and Chl-poor seedlings. Plant Physiol. 1988;86:652-654. http://dx.doi.org/10.1104/pp.86.3.652

20. Weiss D. Regulation of flower pigmentation and growth: multiple signaling pathways control anthocyanins synthesis in expanding petals. Physiol Plant. 2000;110:152-157. http://dx.doi. org/10.1034/j.1399-3054.2000.110202.x

21. Boss PK, Davies C, Robinson S. Analysis of the expression of anthocyanin pathway genes in developing Vitis vinifera L. cv Shiraz grape berries and the implications for pathway regulation. Plant Physiol. 1996;111:1059-1066

22. Vitrac X, Larronde F, Krisa S, Decendit A, Deffieux G, Merillon JM Sugar sensing and $\mathrm{Ca}^{2+}$ calmodulin requirement in Vitis vinifera cells producing anthocyanins. Phytochemistry. 2000;53:659-665. http:// dx.doi.org/10.1016/S0031-9422(99)00620-2

23. Tsukaya H, Ohshima T, Naito S, Chino M, Komeda Y. Sugar-dependent expression of the CHS-A gene for chalcone synthase from petunia in transgenic Arabidopsis. Plant Physiol. 1991;97:1414-1421. http:// dx.doi.org/10.1104/pp.97.4.1414

24. Nagira Y, Ozeki Y. A system in which anthocyanin synthesis is induced in regenerated torenia shoots. J Plant Res. 2004;117:377-383. http:// dx.doi.org/10.1007/s10265-004-0170-6

25. Kim JS, Lee BH, Kim SH, Oh KH, Yun CK. Response to environmental and chemical signals for anthocyanin biosynthesis in nonchlorophyllous corn (Zea mays L.) leaf. J Plant Biol. 2006;49:16-25. http://dx.doi. org/10.1007/BF03030784

26. Dai ZW, Meddar M, Renaud C, Hilbert G, Delrot S, Gomes E. Longterm in vitro cultures of grape berries and its application to assess the effects of sugar supply on anthocyanin accumulation. J Exp Bot. 2014;65(13):1-13. http://dx.doi.org/10.1093/jxb/ert489

27. Teng S, Keurentjes J, Bentsink L, Koornneef M, Smeekens S. Sucrosespecific induction of anthocyanin biosynthesis in Arabidopsis requires the MYB75/PAP1 gene. Plant Physiol. 2005;139:1840-1852. http:// dx.doi.org/10.1104/pp.105.066688

28. Hiratsuka S, Onodera H, Kawai Y, Kubo T, Itoh H, Wada R. ABA and sugar effects on anthocyanin formation in grape berry cultured in vitro. Sci Hortic (Amsterdam). 2001;90:121-130. http://dx.doi. org/10.1016/S0304-4238(00)00264-8

29. Reinbothe S, Mollenhauer B, Reinbothe C. JIPs and RIPs: the regulation of plant gene expression by jasmonates in response to environmental cues and pathogens. Plant Cell. 1994;6:1197-1209. http://dx.doi.org/10.1105/tpc.6.9.1197

30. Belhadj A, Telef N, Saigne C, Cluzet S, Barrieu F, Hamdi S, et al. Effect of methyl jasmonate in combination with carbohydrates on gene expression of PR proteins, stilbene and anthocyanin accumulation in grapevine cell cultures. Plant Physiol Biochem. 2008;46:439-499. http://dx.doi.org/10.1016/j.plaphy.2007.12.001

31. See KS, Bhatt A, Keng CL. Effect of sucrose and methyl jasmonate on biomass and anthocyanin production in cell suspension culture of Melostoma malabathricum (Melastomaceae). Rev Biol Trop. 2011;59:597-606.

32. Shimizu Y, Maeda K, Kato M, Shimomura K. Methyl jasmonate induces anthocyanin accumulation in Gynura bicolor cultured roots. In Vitro Cell Dev Biol Plant. 2010;46:460-465. http://dx.doi.org/10.1007/ s11627-010-9294-7

\section{Wpływ cukrów na akumulację antocyjanów indukowanych przez jasmonian metylu w korzeniach Kalanchoe blossfeldiana (Poelln.)}

\section{Streszczenie}

Badano wpływ cukrów, sacharozy, glukozy i fruktozy oraz alkoholi cukrowych, mannitolu i sorbitolu podanych pojedynczo i łącznie z jasmonianem metylu (JA-Me) na akumulację antocyjanów w korzeniach roślin Kalanchoe blossfeldiana. Cukry i alkohole cukrowe zastosowane pojedynczo nie miały wpływu na akumulację antocyjanów w korzeniach roślin całych. Korzenie były kremowe jak w kontroli. Sacharoza w stężeniu 0.5\% i 3.0\% oraz glukoza w stężeniu 3.0\% hamowały akumulację antocyjanów indukowaną przez jasmonian metylu. Tylko fruktoza w stężeniu 3.0\% stymulowała akumulację antocyjanów indukowaną przez JA-Me. Zastosowane w pracy alkohole cukrowe, mannitol w stężeniu 3.0\% i sorbitol $(0.5 \%$ and $3.0 \%)$ hamowały akumulację antocyjanów indukowaną przez JA-Me w korzeniach całych roślin.

W korzeniach izolowanych (odciętych) zarówno cukry/alkohole cukrowe, jak i jasmonian metylu podane pojedynczo nie wpływały na akumulację antocyjanów. Nie obserwowano również akumulacji antocyjanów po podaniu alkoholi cukrowych z JA-Me. Jednak łączne traktowanie odciętych korzeni cukrami (sacharoza, glukoza, fruktoza) z jasmonianem metylu powodowało nagromadzenie antocyjanów, ale głównie w części wierzchołkowej korzenia. Wyniki te sugerują, że akumulacja antocyjanów w korzeniach $K$. blossfeldiana przez jasmonian metylu może być zależna od interakcji JA-Me z cukrami transportowanymi z łodyg (liście) do korzeni. 